\title{
ACTIVITY PATTERN SEGREGATION OF CARNIVORES IN THE HIGH ANDES
}

\author{
Mauro Lucherini,* Juan I. Reppucci, R. Susan Walker, M. Lilian Villalba, Alvaro Wurstten, Giovana Gallardo, \\ Agustin Iriarte, Rodrigo Villalobos, and Pablo Perovic \\ GECM-Cátedra Fisiología Animal, Departamento Biología, Bioquímica y Farmacia, Universidad Nacional de \\ Investigaciones Científicas y Técnicas (CONICET), San Juan 670, 8000 Bahía Blanca, Argentina (ML, JIR) \\ Wildlife Conservation Society, Neuquén, Argentina (RSW, AW) \\ Colección Boliviana de Fauna, La Paz, Bolivia (MLV) \\ Centro de Estudios en Biología Teórica y Aplicada (BIOTA), La Paz, Bolivia (GG) \\ Fundación Biodiversitas, CASEB, Pontifica Universidad Católica de Chile, Santiago, Chile (AI, RV) \\ IByGeo-Museo de Ciencias Naturales, Universidad Nacional de Salta, Argentina (PP)
}

\begin{abstract}
Intraguild competition may be reduced if ecologically similar species segregate temporally. Using data from 1,596 camera-trap photos, we present the 1st quantitative analyses of the activity patterns of Andean cats (Leopardus jacobita), Pampas cats (Leopardus colocolo), culpeos (Lycalopex culpaeus), and pumas (Puma concolor) in high-altitude deserts of the Andes. We compared daily activity patterns for these carnivores with those of mountain vizcachas (Lagidium viscacia), the main prey of Andean cats. Activity patterns of all species were positively skewed toward night. Pampas cats displayed the greatest proportion of nocturnal activity, whereas Andean cats were the most diurnal. Activity of Andean cats differed significantly only from that of Pampas cats; Pampas cats also differed from pumas. Activity of Andean cats was generally similar to that of mountain vizcachas. The dissimilar activity patterns of Andean and Pampas cats support the hypothesis of temporal niche segregation of these felids.
\end{abstract}

Key words: camera trapping, intraguild competition, Lagidium viscacia, Lycalopex culpaeus, Leopardus colocolo, Leopardus jacobita, Puma concolor, South America

Activity patterns of animals are determined by numerous factors. Abiotic environmental factors such as light and temperature may influence optimum daily and seasonal activity patterns (e.g., Nielsen 1983; Patterson et al. 1999). Body mass, human disturbance, social behavior, predator avoidance, prey acquisition, and competition also may affect activity in different forms (e.g., Bunnell and Harestad 1990; O’Donoghue et al. 1998; Rogowitz 1997). As a result, knowing when animals are active may be important for understanding their ecological niche and, hence, developing conservation plans for imperiled species (Hwang and Garshelis 2007).

The Andean cat (Leopardus jacobita), the Pampas cat (Leopardus colocolo), and the culpeo (Lycalopex culpaeus) are medium-sized carnivores found in arid, high-altitude regions in the Andes of Peru, Bolivia, Argentina, and Chile (Villalba

*Correspondent: lucherinima@yahoo.com

\section{(C) 2009 American Society of Mammalogists} www.mammalogy.org et al. 2004). Increasing evidence suggests that the ranges of these species overlap greatly in the High Andes and that these animals co-occur at the local scale (Lucherini and Luengos Vidal 2003; Lucherini et al. 2008a; Perovic et al. 2003). Intraguild competition has been found to have significant negative effects on carnivore populations (Linnell and Strand 2000; Palomares and Caro 1999), leading to speculation that competition within this South American guild of carnivores may be impacting the most endangered of these species, the Andean cat (Lucherini and Luengos Vidal 2003; Napolitano et al. 2008; Walker et al. 2007a). Interspecific competition can take 2 forms: exploitation and interference. In many cases, in the presence of larger species, small carnivores are affected by both types of competition and their density can be strongly reduced when compared to that expected solely on the basis of prey abundance (Linnell and Strand 2000). Because relative body size is the primary determinant of interspecific killing (Donadio and Buskirk 2006; Fedriani et al. 1999), smaller carnivores in the High Andes can be expected to segregate ecologically with the puma (Puma concolor), the largest carnivore occurring in the region, because of predation risk. 
Dietary overlap is expected to increase the potential for competition (Donadio and Buskirk 2006); recent studies have reported a relatively high degree of dietary overlap among carnivores in the High Andes, with both culpeos and Pampas cats preying upon mountain vizcachas (Lagidium viscacia), which are the primary prey of the Andean cat (Napolitano et al. 2008; Viscarra Siñani 2008; Walker et al. 2007a).

Intraguild competition may be reduced if ecologically similar species partition their activity temporally (Di Bitetti et al. 2009; Kronfeld-Schor and Dayan 2003). Accordingly, we predicted that temporal segregation of activity would be evident between the species with the greatest potential for competition, namely culpeos and Andean and Pampas cats. Because the Andean cat appears to be the predator most specialized on vizcachas (Walker et al. 2007a), we predicted that activity pattern for this felid should be most similar to that for vizcachas. Here, we test these predictions using cameratrap data obtained from multiple localities in the High Andes. In addition to providing the 1st quantitative data on the activity patterns of Andean cats, Pampas cats, culpeos, and pumas in high-altitude deserts of the Andes, our analyses also will improve our ability to make sound conservation decisions regarding these rare and threatened species.

\section{Materials And Methods}

Camera trapping is a noninvasive technique that has been applied successfully to collect information on secretive mammals such as nocturnal carnivores (e.g., Karanth et al. 2004; Kucera and Barrett 1993). In addition to documenting the presence and abundance of such taxa, camera traps that record the date and time at which photos are taken can be used to study the activity patterns of carnivores and other mammals (e.g., Cuéllar et al. 2006; Di Bitetti et al. 2006; Grassman et al. 2006; Maffei et al. 2004; Van Schaik and Griffiths 1996).

Activity data were obtained from 13 sites located in Argentina, Bolivia, and Chile, which represent 3 of the 4 countries in which the Andean cat occurs (Fig. 1); cameratrapping surveys were completed as part of studies conducted by the Andean Cat Alliance. Several different models of camera trap were employed (Camtrakker $35 \mathrm{~mm}$ was the predominant model; Camtrakker, Watkinsville, Georgia); all used passive infrared detection systems that were programmed to operate continuously and, in most cases, to record the date or hour, or both, of each photograph. To maximize the chances of photographing a carnivore, traps were placed at a height of approximately $30 \mathrm{~cm}$ along animal trails close to sites where carnivore signs were observed; in most cases, a lure (bobcat gland or bobcat urine) was placed on the ground in front of the camera. Trapping periods and effort varied among sites.

To avoid pseudoreplication, when the same camera trap took more than 1 photograph of the same carnivore species in less than $1 \mathrm{~h}$, we counted these photos as 1 event and used the time at which the 1st photo was taken for subsequent analyses of activity. In the case of mountain vizcachas, which live in large colonies with a high density of animals, we adopted a

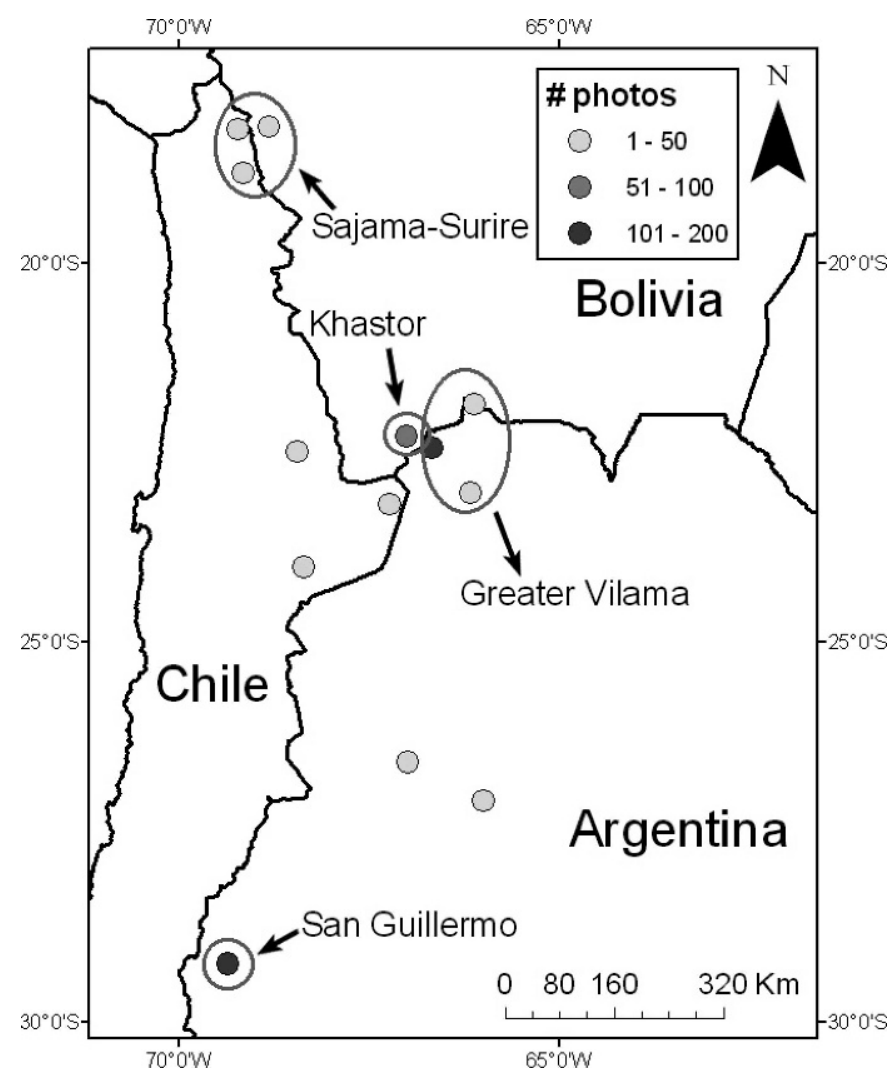

Fig. 1.-Localities $(n=13)$ at which camera traps were deployed in Argentina, Bolivia, and Chile. The approximate number of photos collected at each site is indicated. Ellipses denote regions listed in Table 1.

30-min interval to avoid discarding a large number of photographs that probably corresponded to different individuals. Because per-site and per-hour sample sizes were small in some cases, we pooled the data from all study sites and divided the photos obtained into 4 time periods: day, night, dawn (from $1 \mathrm{~h}$ before to $1 \mathrm{~h}$ after sunrise), and dusk (from $1 \mathrm{~h}$ before to $1 \mathrm{~h}$ after sunset-Theuerkauf et al. 2003). We used log-likelihood ratio tests to determine if activity for each species was homogeneously distributed across these 4 temporal periods and to compare activity patterns among species. To avoid an excess of small $(<5)$ expected values, data from dawn and dusk were pooled for these tests; these periods were combined because their samples were the smallest and because of their similar light conditions. To compare activity patterns between species more directly, for each dyad of species we calculated a similarity coefficient index using the percentage similarity $(P)$ of Renkonen (Krebs 1998):

$$
P_{j k}=\left[\sum_{i=1}^{n}\left(\operatorname{minimum} p_{i j}, p_{i k}\right)\right] 100,
$$

where $P_{j k}$ is percentage temporal overlap between species $j$ and $k, p_{i j}$ is proportion of the photos in time class $i$ by species $j$, $p_{i k}$ is proportion of photos in time class $i$ by species $k$, and $n$ is total number of time classes. Values of this index range from 0 
Table 1.-Number of photos obtained by sampling region for 4 species of carnivores monitored by camera trapping in the High Andes.

\begin{tabular}{lccccr}
\hline & Andean cat & Pampas cat & Culpeo & Puma & Total \\
\hline Khastor (Bolivia) & 38 & 7 & 28 & 0 & 73 \\
Greater Vilama (Argentina) & 36 & 58 & 57 & 2 & 153 \\
San Guillermo (Argentina) & 0 & 11 & 83 & 17 & 111 \\
Sajama-Surire & & & & & \\
$\quad$ Chile-Bolivia) & 7 & 2 & 12 & 13 & 34 \\
Other sites (pooled) & 12 & 12 & 74 & 17 & 115 \\
Total & 93 & 90 & 254 & 49 & \\
\hline
\end{tabular}

to 1 , indicating, respectively, no similarity and complete similarity.

The activity of numerous nocturnal mammals is known to vary with the lunar cycle (e.g., Di Bitetti et al. 2006; Kauhala et al. 2006; O'Farrel 1974), presumably because bright moonlight increases the detectability of both prey and predators. To explore the effect of this variable on our activity analyses, activity from all sites was examined as a function of lunar cycle. Data from all species except pumas were pooled for this analysis; pumas were excluded because of sample size. We grouped all night photos into 5 lunar classes: moonless (moon not present or not visible) and 4 categories of increasing brightness, defined by the percentage of illuminated moon $(1-25 \%, 26-50 \%, 51-75 \%$, and $76-100 \%)$ visible at the time of the photo. In general, the study area is characterized by clear skies throughout the year. As a result, the percentage of moon visible was determined from the monthly lunar cycle (e.g., quarter moon $=25 \%$ illuminated moon visible). We used a Kolmogorov-Smirnov test to compare the observed frequency distribution of photos across different moonlight categories against an expected probability distribution generated using 323 points in time (randomly selected from throughout the year) to which we assigned the corresponding category of lunar illumination.

\section{Results}

We obtained 1,099 distinct photos of mountain vizcachas and 497 distinct photos of carnivores. These consisted of 93 (19.1\%) photos of Andean cats, 90 (18.7\%) of Pampas cats, 49 $(10.1 \%)$ of pumas, $254(51.1 \%)$ of culpeos, and $11(2.2 \%)$ of Molina's hog-nosed skunk (Conepatus chinga). Four main geographical groups of sites could be recognized (Fig. 1; Table 1). For these pooled samples, the mean number of photos per site was $92.8 \pm 51 \pm S D$ (range $=34-153, n=4$ sites). The largest set of photos was obtained from the Greater Vilama area in northwestern Argentina (Fig. 1; Table 1).

Although photos of the felid and canid species detected were distributed throughout the 4 time periods considered (Fig. 2), photos of hog-nosed skunks were taken exclusively at night. For this reason and because of the small total number of photos for skunks, data for $C$. chinga were excluded from subsequent analyses. For each of the remaining species, although $\geq 20 \%$ of photos were recorded during the daytime,

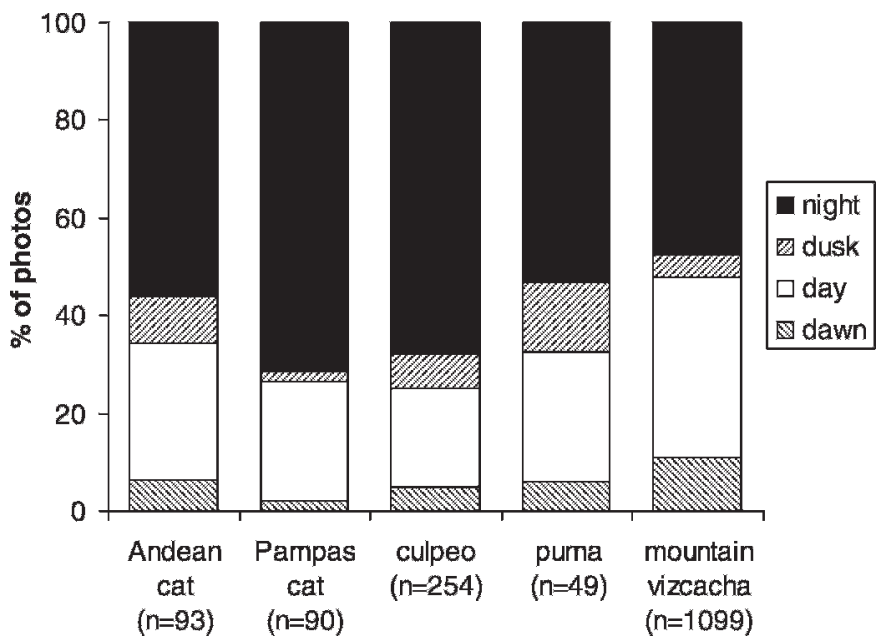

Fig. 2.-Activity patterns for 4 species of carnivores plus mountain vizcachas, as determined from camera trapping in the high-altitude Andes. The sample size for each species is noted. Data represent the percentage of photos occurring within each of 4 designated subsets of the 24-h light cycle.

activity was significantly biased toward night (all likelihood ratio tests $>30$, d.f. $=2$, all $P<0.0001$; Fig. 2). Pampas cats had the highest proportion $(71.1 \%)$ of nocturnal activity, whereas Andean cats had the greatest proportion $(28 \%)$ of daytime photos. Andean cats and pumas displayed the greatest proportions (34.4\% and $32.7 \%$, respectively) of crepuscular (dawn and dusk) activity. Although the bias toward nocturnal activity was less evident for mountain vizcachas, these rodents were recorded 1.3 times more frequently at night than during the day (Fig. 2).

Overall, interspecific variation was detected in the percentage of photos recorded during each of the 4 temporal periods considered (likelihood ratio test $=55.5$, d.f. $=8, P<0.0001$ ) Subsequent pairwise comparisons of carnivore species revealed significant differences in activity between Andean and Pampas cats and between Pampas cats and pumas (Table 2). Pairwise comparisons also revealed that although activity of mountain vizcachas differed from that of both Pampas cats

TABLE 2.-Pairwise comparisons of activity patterns for 4 species of Andean carnivores and mountain vizcachas. For each pairwise comparison, the upper half of the table (above the diagonal) shows the likelihood ratio value and corresponding $P$-value $(d . f .=2$ in all cases), whereas the lower half of the table (below the diagonal) presents the values of the Renkonen similarity coefficient index. Significant values for likelihood ratios $(P<0.05)$ are noted in bold type.

\begin{tabular}{|c|c|c|c|c|c|c|c|c|}
\hline \multirow{2}{*}{ Andean cat } & \multirow{2}{*}{$\begin{array}{c}\begin{array}{c}\text { Andean } \\
\text { cat }\end{array} \\
-\end{array}$} & \multirow{2}{*}{$\begin{array}{c}\text { Pampas cat } \\
8.31 \mathbf{0 . 0 1 6}\end{array}$} & \multicolumn{2}{|c|}{ Culpeo } & \multicolumn{2}{|c|}{$\begin{array}{c}\text { Mountain } \\
\text { vizcacha }\end{array}$} & \multicolumn{2}{|c|}{ Puma } \\
\hline & & & 4.01 & 0.26 & 3.35 & 0.187 & 0.4 & 0.82 \\
\hline Pampas cat & 84.8 & - & 5.37 & 0.068 & 21.5 & $<\mathbf{0 . 0 0 1}$ & 9.28 & 0.01 \\
\hline Culpeo & 88.3 & 92.2 & - & & 36 & $<0.001$ & 3.93 & 0.14 \\
\hline $\begin{array}{l}\text { Mountain } \\
\text { vizcacha }\end{array}$ & 90.8 & 76.5 & 80 & & - & & 2.50 & 0.274 \\
\hline Puma & 95.7 & 82.0 & 85.5 & & 89.4 & & - & \\
\hline
\end{tabular}




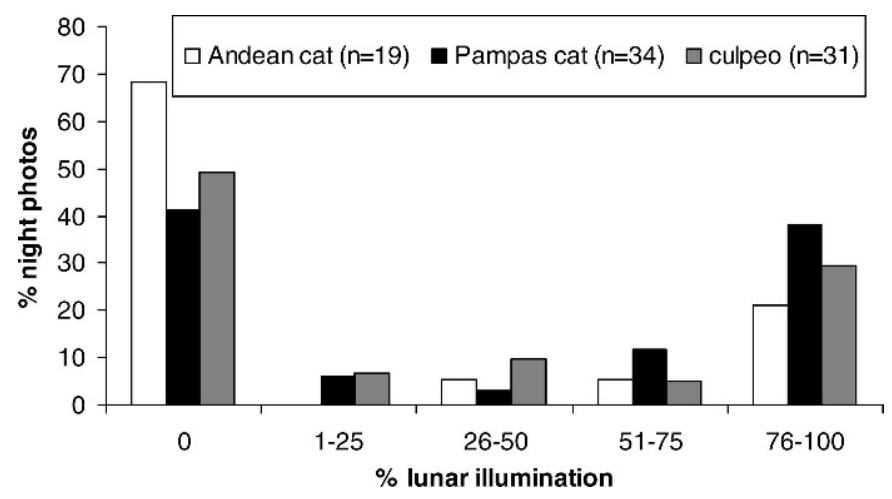

Fig. 3. - Percentage of nocturnal photos of Andean carnivores as a function of degree of lunar illumination. Sample size for each species is indicated.

and culpeos, no differences in activity were found between vizcachas and either Andean cats or pumas (Table 2). Accordingly, similarity indices revealed that activity patterns were most similar for Andean cats, pumas, and vizcachas, with less similarity detected between Andean and Pampas cats or between Pampas cats and vizcachas (Table 2). Collectively, these findings suggest that activity of Pampas cats is distinct from that of Andean cats and their vizcacha prey.

Andean cats, Pampas cats, and culpeos were all most active during moonless periods (Fig. 3). Interestingly, the 2nd highest percentage of photos for each species was recorded during periods of maximal lunar illumination (Fig. 3). Although Andean cats appeared to be more active during moonless periods than Pampas cats and culpeos (Fig. 3), none of these species showed significant departures from expected patterns of activity, as determined from the frequencies of the different moonlight luminosity categories $(Z=0.4-0.8, d . f$. $=$ $4, P>0.05$ for all species), suggesting that predator activity in our study was not influenced by moonlight.

\section{DisCUSSION}

The niche complementarity hypothesis asserts that a high degree of overlap in 1 niche component should be associated with a low degree of overlap in at least 1 other niche dimension (Jiménez et al. 1996; Schoener 1974). Previous studies revealed little evidence of resource partitioning between Pampas and Andean cats. Although the distribution of scats in northern Chile suggested that these species may segregate altitudinally (Napolitano et al. 2008), these authors reported considerable spatial overlap, confirming the suggestion that the spatial distributions of these species overlap substantially (Lucherini and Luengos Vidal 2003; Lucherini et al. 2008a; Perovic et al. 2003).

Temporal segregation is another mechanism that ecologically similar species can use to avoid competition (KronfeldSchor and Dayan 2003). Examination of our data suggests that temporal niche segregation may occur between Andean and Pampas cats. The finding that the activity patterns of these 2 felids were more dissimilar than those of other sympatric carnivores is consistent with the prediction that the degree of niche segregation between 2 species tends to increase as their relatedness and morphological similarity increase (Donadio and Buskirk 2006; Odum 1966). In contrast, no evidence of temporal partitioning was found between these felids and culpeos. Culpeos are thought to be greater habitat and dietary generalists than either Andean or Pampas cats (Lucherini et al. 2008b; Viscarra Siñani 2008; Walker et al. 2007a), suggesting that these species can co-occur in the absence of pronounced temporal or other partitioning of the environment.

Because mountain vizcachas are the primary prey item of Andean cats (Napolitano et al. 2008; Walker et al. 2007a) and one of the most important food items-based on biomass ingested - for the other medium-sized carnivores of the High Andes, we had predicted that the activity pattern of this rodent would influence those of its predators. Mountain vizcachas have been described as diurnal-crepuscular (Redford and Eisenberg 1992; Walker et al. 2007b), but examination of our camera-trapping data indicated that they were primarily nocturnal, with a major peak of activity occurring at dawn in high-altitude areas. As expected, Andean cats exhibited a similar pattern of daily activity, whereas the activity pattern for Pampas cats differed from that of vizcachas, which is in agreement with the hypothesis that Andean cats are morphologically specialized to prey on mountain vizcachas (Nowell and Jackson 1996). Thus, dietary specialization on vizcachas appears to be reflected in the activity patterns of the felids examined.

Comparisons of our findings with previously published studies suggest that the activity patterns of the study species may vary geographically. For example, although culpeos in both southern (Johnson and Franklin 1994) and north-central Chile (Salvatori et al. 1999) were active primarily at night, this pattern was less pronounced at the north-central locality. Although examination of our data indicated that Pampas cats were largely nocturnal, in central Brazilian grasslands (the only other area where their activity has been studied), these animals were almost exclusively diurnal (Silveira et al. 2005). This striking discrepancy in activity patterns may be related to the large difference in habitat characteristics between sites, but also may be a consequence of the need to avoid niche overlap with sympatric carnivores in a different guild.

We found evidence of temporal overlap of 2 medium-sized carnivores (culpeos and Andean cats) with pumas, the topranking predator of the High Andes. Because relative body size of competitors is the primary determinant of interspecific killing (Donadio and Buskirk 2006), we suggest that these species show segregation in other components of the ecological niche, namely the trophic niche. The puma is the only predator able to prey upon the large mammals occurring in the region (vicuñas [Vicugna vicugna] and livestock, such as llamas, donkeys, goats, and sheep), and the scarce information available on its food habits (Cajal and López 1998; Perovic 1998) as well as interviews with local people (Lucherini and Merino 2008; Lucherini et al. 2008b) indicate that large mammals make up most of the diet of pumas. 
Because trophic overlap has been recognized as influential in predisposing intraguild attacks (Donadio and Buskirk 2006), diet segregation could facilitate tolerance by pumas, especially toward Andean cats, which showed the greatest similarity in activity patterns.

In summary, our results suggest that temporal partitioning contributes to ecological niche segregation among carnivores in the high-altitude Andes. Although our sample sizes, particularly of pumas, are relatively small, studies of these elusive animals are difficult and our data provide the 1 st quantitative evidence that daily activity patterns differ among these species, notably the trophically similar Andean and Pampas cats. This temporal segregation may favor the coexistence of these 2 small cats and decrease the importance of intraguild competition as a threat for conservation of the endangered Andean cat.

\section{RESUMEN}

La segregación temporal entre especies ecológicamente similares puede reducir la competición intragremial. Sobre la base de 1,596 fotos de trampas cámaras, se presentan los primeros análisis cuantitativos sobre los patrones de actividad del gato andino (Leopardus jacobita), gato de los pajonales (Leopardus colocolo), zorro culpeo (Lycalopex culpaeus) y puma (Puma concolor) en los desiertos de altura de los Andes. Se comparan los patrones de actividad de estos carnívoros con los del chinchillón (Lagidium viscacia), la presa principal del gato andino. Los patrones de actividad de todas las especies mostraron un sesgo positivo hacia la noche. El gato de los pajonales tuvo la mayor proporción de actividad nocturna y el gato andino de diurna. La actividad del gato andino difirió en forma significativa únicamente de la del gato de los pajonales; los patrones de este último se diferenciaron también del puma. La actividad del gato andino fue en general similar a la del chinchillón. La diferencia entre gato andino y de los pajonales apoya la hipótesis de segregación entre los nichos temporales de estos félidos.

\section{ACKnowledgments}

We are grateful to E. Delgado, P. Cuello, E. Luengos, C. Tellaeche, and all the volunteers and villagers who contributed to data collection, as well as to E. Casanave (Universidad Nacional del Sur), WildCRU (University of Oxford), and the other members of the Andean Cat Alliance for providing advice. Two anonymous referees and E. Lacey greatly improved a previous version of this paper. Our project received support from Wildlife Conservation Network, Darwin Initiative, BP Conservation Programme, Whitley Fund for Nature, Wild About Cats, Cat Action Treasury, Cleveland Zoological Society, Rufford Foundation, International Society for Endangered Cats Canada, and La Torbiera Zoological Society. We acknowledge all the governmental institutions that endorsed and authorized our project, and Administración de Parques Nacionales Argentinos, Reserva Nacional de Fauna Andina Eduardo Avaroa, Colección Boliviana de Fauna for their support. JIR was supported by doctoral scholarships from CONICET.

\section{Literature Cited}

Bunnell, F. L., And A. S. Harestad. 1990. Activity budgets and body weight in mammals. How sloppy can mammals be? Current Mammalogy 2:245-305.

CAJAL, J. L., AND N. LóPEz. 1998. El mayor carnívoro de los Andes: el puma. Pp. 175-180 in Bases para la conservación y manejo de la puna y cordillera frontal de Argentina. El rol de las Reservas de Biosfera (J. L. Cajal, J. G. Fernández, and R. Tecchi, eds.). Fucema, UNESCO, Uruguay.

CuÉllar, E., L. Maffei, R. Arispe, and A. Noss. 2006. Geoffroy's cats at the northern limits of their range: activity patterns and density estimates from camera trapping in Bolivian dry forests. Neotropical Fauna and Environment 41:169-177.

Di Bitetti, M. S., Y. E. Di Blanco, J. A. Pereira, and A. Paviolo. 2009. Time partitioning favors the coexistence of sympatric crabeating foxes (Cerdocyon thous) and pampas foxes (Lycalopex gymnocercus). Journal of Zoology (London).

Di Bitetti, M. S., A. Paviolo, and C. De Angelo. 2006. Density, habitat use and activity patterns of ocelots (Leopardus pardalis) in the Atlantic Forest of Misiones, Argentina. Journal of Zoology (London) 270:153-163.

Donadio, E., AND S. W. BuskiRK. 2006. Diet, morphology, and interspecific killing in carnivora. American Naturalist 167:524536.

Fedriani, J. M., F. Palomares, and M. Delibes. 1999. Niche relations among three sympatric Mediterranean carnivores. Oecologia 121:138-148.

Grassman, L. I., JR., A. M. Haines, J. E. JaneĉKa, And M. E. Tewes. 2006. Activity periods of photo-captured mammals in north central Thailand. Mammalia 48:306-309.

Hwang, M. H., AND D. L. Garshelis. 2007. Activity patterns of Asiatic black bears (Ursus thibetanus) in the Central Mountains of Taiwan. Journal of Zoology (London) 271:203-209.

Jiménez, J. E., J. L. YÁÑez, E. L. Tabilo, and F. M. Jaksic. 1996. Niche complementariety of South American foxes: reanalysis and test of a hypothesis. Revista Chilena de Historia Natural 69:113123.

Johnson, W. E., And W. L. Franklin. 1994. Spatial resource partitioning by sympatric grey fox (Dusicyon griseus) and culpeo fox (Dusicyon culpaeus) in southern Chile. Canadian Journal of Zoology 72:1788-1793.

Karanth, K. U., J. D. Nichols, and N. S. Kumar. 2004. Photographic sampling of elusive mammals in tropical forests. Pp. 229-247 in Sampling rare or elusive species: concepts, designs, and techniques for estimating population parameters (W. L. Thompson, ed.). Island Press, Washington, D.C.

Kauhala, K., K. Holmala, and J. Schregel. 2006. Seasonal activity patterns and movements of the raccoon dog, a vector of diseases and parasites, in southern Finland. Mammalian Biology 72:342353.

Krebs, C. 1998. Ecological methodology. 2nd ed. Addison Wesley Longman, Menlo Park, California.

Kronfeld-Schor, N., ANd T. Dayan. 2003. Partitioning of time as an ecological resource. Annual Review of Ecology and Systematics 34:153-181.

Kucera, T. E., And R. H. Barrett. 1993. The Trailmaster ${ }^{\circledR}$ camera system for detecting wildlife. Wildlife Society Bulletin 21:505508 .

LinNell, J. D. C., AND O. STRAnd. 2000. Interference interactions, coexistence and conservation of mammalian carnivores. Diversity and Distribution 6:169-176. 
LuCHERINI, M., AND E. Luengos Vidal. 2003. Intraguild competition as a potential factor affecting the conservation of two endangered cats in Argentina. Endangered Species Updates 2:211-220.

Lucherini, M., E. Luengos Vidal, And M. J. Merino. 2008a. How rare is the rare Andean cat? Mammalia 72:95-101.

LuCHERINI, M., AND M. J. MERINO. 2008. Human-carnivore conflicts in the high-altitude Andes of Argentina. Mountain Research and Development 28:81-85.

Lucherini, M., L. Rios, C. Manfredi, M. J. Merino, and J. Arellano. 2008b. Human-puma conflicts in three areas from the southern cone of South America: preliminary data. Cat News 49:29-30.

Maffei, L., E. Cuéllar, And A. Noss 2004. One thousand jaguars (Panthera onca) in Bolivia's Chaco? Camera trapping in the KaaIya National Park. Journal of Zoology (London) 262:295-304.

Napolitano, C., ET AL. 2008. Ecological and biogeographic inferences on two sympatric and enigmatic Andean cat species using genetic identification of fecal samples. Molecular Ecology 17:678-690.

Nielsen, E. T. 1983. Relation of behavioural activity rhythms to the changes of day and night. A revision of views. Behaviour 89:147-173.

Nowell, K., AND P. JACKSON. 1996. Wild cats: status survey and conservation action plan. IUCN/SSC Cat Specialist Group, Gland, Switzerland.

O’Donoghue, M., S. Boutin, C. J. Krebs, D. L. Murray, and E. J. Hofer. 1998. Behavioral responses of coyotes and lynx to the snowshoe hare cycle. Oikos 82:169-183.

Odum, E. P. 1966. Ecologia. Zanichelli, Bologna, Italy.

O'FArrel, M. J. 1974. Seasonal activity patterns of rodents in a sagebrush community. Journal of Mammalogy 55:809-823.

Palomares, F., and T. M. Caro. 1999. Interspecific killing among mammalian carnivores. American Naturalist 153:492-508.

Patterson, B. R., S. Bondrup-Nielsen, And F. Messier. 1999. Activity patterns and daily movements of the eastern coyote, Canis latrans, in Nova Scotia. Canadian Field Naturalist 113:251-257.

Perovic, P. 1998. La comunidad de carnívoros en la Reserva de Biosfera Laguna de Pozuelos. Pp. 182-188 in Bases para la conservación y manejo de la puna y cordillera frontal de Argentina. El rol de las Reservas de Biosfera (J. L. Cajal, J. G. Fernández, and R. Tecchi, eds.). Fucema, UNESCO, Uruguay.

Perovic, P., S. Walker, and A. Novaro. 2003. New records of the endangered Andean mountain cat in northern Argentina. Oryx 37:374-377.
Redford, K. H., and J. F. Eisenberg. 1992. Mammals of the Neotropics: Chile, Argentina, Uruguay, Paraguay. University of Chicago Press, Chicago, Illinois.

Rogowitz, G. L. 1997. Locomotor and foraging activity of the whitetailed jackrabbit (Lepus townsendii). Journal of Mammalogy 78:1172-1181.

Salvatori, V., G. Vaglio-Laurin, P. L. Meserve, L. Boitani, and A. Campanella. 1999. Spatial organization, activity, and social interactions of culpeo foxes (Pseudalopex culpaeus) in northcentral Chile. Journal of Mammalogy 80:980-985.

Schoener, T. W. 1974. Resource partitioning in ecological communities. Science 185:27-39.

Silveira, L., A. T. A. Jácomo, and M. Malzoni Furtado. 2005. Pampas cat ecology and conservation in the Brazilian grasslands. Project of the Month, Cat Specialist Group Web site. http://www. catsg.org/catsgportal/project-o-month/02_webarchive/grafics/ sept2005.pdf. Accessed 16 March 2009.

Theuerkauf, J., ET AL. 2003. Daily patterns and duration of wolf activity in the Białowieża Forest, Poland. Journal of Mammalogy 84:243-253.

VAN Schaik, C. P., AND M. GRIFFIths. 1996. Activity periods of Indonesian rain forest mammals. Biotropica 28:105-112.

Villalba, L., ET AL. 2004. The Andean cat: conservation action plan. Andean Cat Alliance, La Paz, Bolivia.

VisCARRA SiÑAnI, M. E. 2008. Evaluación de la distribución, densidad y dieta de carnívoros en cuatro tipos de hábitats en un área de la provincia Sud Lípez (Potosí-Bolivia). Graduation thesis, Universidad Mayor de San Andrés, La Paz, Bolivia.

WAlker, R. S., ET AL. 2007a. Diets of three species of Andean carnivores in high-altitude deserts of Argentina. Journal of Mammalogy 88:519-525.

Walker, R. S., A. Novaro, and L. C. Branch. 2007b. Functional connectivity defined through cost-distance and genetic analyses: a case study for the rock-dwelling mountain vizcacha (Lagidium viscacia) in Patagonia, Argentina. Landscape Ecology 22:13031314.

Submitted 2 January 2009. Accepted 6 April 2009.

Associate Editor was Eileen A. Lacey. 